\title{
Corrosion Behaviour of CuAINi SMA in different Coastal Environments
}

\author{
Gyöngyi Vastag ${ }^{1, *}, \check{S}_{\text {piro Ivošević }}^{2}$, Danilo Nikolić ${ }^{2}$, Goran Vukelić3 ${ }^{3}$, Rebeka Rudolf ${ }^{4}$ \\ ${ }^{1}$ University Novi Sad, Faculty of Sciences, Trg Dositeja Obradovića 3, 21000 Novi Sad, Serbia \\ ${ }^{2}$ Faculty of Maritime Studies Kotor, University of Montenegro, Put I Bokeljske brigade 44, 85330 \\ Kotor, Montenegro \\ ${ }^{3}$ University of Rijeka, Faculty of Maritime Studies, Studentska 2, 51000 Rijeka, Croatia \\ ${ }^{4}$ University of Maribor, Faculty of Mechanical Engineering, Smetanova ulica 17, 2000 Maribor, \\ Slovenia \\ *E-mail: djendji.vastag@dh.uns.ac.rs
}

Received: 3 March 2021/ Accepted: 30 September 2021 / Published: 10 November 2021

\begin{abstract}
Recently, the usage of different Shape Memory Alloys (SMAs) in the coastal environments has been registered increasingly, so knowledge of their corrosion behaviour is crucial. In accordance with this, the corrosion behaviour of CuAlNi SMA was monitored in different coastal environments after 6 months of exposure time. The corrosion effect of CuAlNi SMA was evaluated by the changes in chemical composition of the surface by using Energy-Dispersive X-ray spectroscopy (EDS). The measured chemical compositions were correlated by using linear regression analysis and selected chemometrics methods (Cluster Analysis and Principal Component Analysis - CA, PCA) with the aim to identify the impact of the environment on the corrosion behaviour of CuAlNi SMA, and to find the correlations between the formatted corrosion products, depending on the given conditions. The obtained results show that the used multivariate methods have the ability to register the impact of selected environments on the corrosion behaviour of CuAlNi SMAs.
\end{abstract}

Keywords: Shape Memory Alloy, CuAlNi, corrosion, coastal environment, chemometrics

\section{$\underline{\text { FULL TEXT }}$}

(C) 2021 The Authors. Published by ESG (www.electrochemsci.org). This article is an open access article distributed under the terms and conditions of the Creative Commons Attribution license (http://creativecommons.org/licenses/by/4.0/). 